\title{
Coping with the Challenges of Urbanization in Low Income Areas: An Analysis of the Livelihood Systems of Slum Dwellers of the Wa Municipality, Ghana
}

\author{
Raqib Abu-Salia' ${ }^{1}$, Issaka Kanton Osumanu' ${ }^{2}$, Abubakari Ahmed ${ }^{3}$ \\ ${ }^{1}$ Department of Development Studies, University for Development Studies, Wa, Ghana \\ ${ }^{2}$ Department of Environment and Resource Studies, University for Development Studies, Wa, Ghana \\ ${ }^{3}$ Institute for Environment and Sanitation Studies, University of Ghana, Accra, Ghana \\ Email: raqueebabu@yahoo.com, kosumanu@uds.edu.gh, abukson1987@gmail.com
}

Received 23 April 2015; accepted 5 June 2015; published 9 June 2015

Copyright (C) 2015 by authors and Scientific Research Publishing Inc.

This work is licensed under the Creative Commons Attribution International License (CC BY).

http://creativecommons.org/licenses/by/4.0/

\section{(c) (i) Open Access}

\begin{abstract}
In Ghana, unplanned and spontaneous urbanization has trapped many in slum dwellings with its attendant poverty, insecurity, and poor housing and general environmental conditions. Slum dwellers' choices of livelihood activities are restricted under various socio-economic and planning constraints. Using mixed methods, this paper explored the conditions under which slum dwellers can maximize the prospects of their environment and minimize the challenges therein. The findings indicate that slum dwellers have diversity of livelihood assets and potentials, yet limited access to planned adaptation remains a main challenge. Many dwellers result to autonomous "supplementary occupations" to cope with the challenges of urbanization. It is therefore imperative to redefine the mandate of urban planning, as a response to spontaneous urbanization, and to develop a tool for sustainable livelihood at the local level.
\end{abstract}

\section{Keywords}

Coping Strategies, Livelihoods, Slums, Urbanization, Vulnerability

\section{Introduction}

In recent times, urban trajectories have been unprecedented. The 2012/2013 State of the World Cities Report estimated that between the periods of 2010 and 2015, there would be an average increment of approximately

How to cite this paper: Abu-Salia, R., Osumanu, I. K., \& Ahmed, A. (2015). Coping with the Challenges of Urbanization in Low Income Areas: An Analysis of the Livelihood Systems of Slum Dwellers of the Wa Municipality, Ghana. Current Urban Studies, 3, 105-118. http://dx.doi.org/10.4236/cus.2015.32010 
200,000 people in the world's urban population (UN-Habitat, 2012). Developing countries in Africa and Asia, but not exclusive, will expect majority of this daily increment of approximately 183,000 (UN-Habitat, 2012). In the developing world, some $13 \%$ of the urban population resides in sub-Saharan Africa, which is also the home of $25 \%$ of slums in the developing countries (UN-Habitat, 2009). While about $90 \%$ of the world's informal settlements and slums are in developing nations, they are a worldwide phenomenon including some European capitals and large American cities (UN Habitat, 2008). Slums are also the most noticeable demonstration of urbanization and poverty in the cities of developing countries, which is one of the targets of the Millennium Development Goals-reducing the number of slum dwellers by 2015. In Ghana, the number of slum dwellers is estimated at 5.9 million as at 2010 (Ghana Statistical Service, 2012). The slum population is set to reach 6.5 million and 7.1 million by the end of 2015 and 2020 respectively, up from 5.4 million in 2005, against a population of 22.5 million (UN-Habitat, 2011). Moreover, according to the National Policy Framework of Ghana, in the year 2010 about 12,545,229 people were living in slums in Ghanaian cities with a 4.25\% growth rate per annum (Republic of Ghana, 2012a).

Related to the debate on the emergence of slums are the conditions affecting livelihood systems of households in these areas, most of whom are poor. Fox (2014: 191) noted that "the challenge of slum is particularly acute for cities in sub-Saharan Africa”. Whereas the emergence and challenges of slum are often associated with the dark side of modernization, which is also a consequence of market failures, Fox (2014) argues that different historical and political dynamics give rise to the recent trajectories in Africa. Recent works on slums have looked at different aspects of the challenges including energy, water supply, sanitation, health, housing demand, and poverty situation (Parikh et al., 2015; Stoler et al., 2015; Aklin et al., 2015; Tumwebaze et al., 2014; Thorn et al., 2015; Patel et al., 2014; Gulyani et al., 2014; Ahmad et al., 2013). There seems to be a consensus that wide infrastructure gap creates preconditions for the deteriorating conditions in slums (United Nations, 2011). Moreover, from a gender perspective, women bear much burden of the deteriorating conditions in slums (Parikh et al., 2012a; Floro \& Swain, 2013). From other perspectives, inferior environmental conditions result in poor health and reduced productivity in slums (Parikh et al., 2012b), yet issues of the coping mechanisms, in terms of the challenges of urbanization, are still acute.

This study seeks to respond to the current predicaments of slum dwellers in Ghana, using Wa as a case study, to demonstrate the conditions within which slum dwellers live, and how these conditions impact their livelihood activities. The major concerns raised are in the areas of how urbanization sets preconditions for secured livelihood and how it affects the ability of slum dwellers to cope with the vulnerabilities of their environment. The concept of livelihoods within slums extends to include social and cultural means which incorporates the command an individual, household or other social groups have over income and/or on bundles of resources that can be used or exchanged to satisfy their desires (Blaikie et al., 2004). A question that arises is to what extent does the current patterns of urbanization facilitate or impede the livelihood systems of slum dwellers in Ghana?

\section{Urbanization and Slum Development in Ghana}

Rapid urbanization implies that developing countries would have the intricacy of mobilizing sufficient resources for development (Adarkwa \& Post, 2001). However, the inability of governments and the private sector to mobilize sufficient resources has led to housing and environmental deficiencies in urban areas of Ghana (NsiahGyabaah, 2009). The result has been the struggle for space and other resources and the development of slums and squatters in many urban areas, which are deficient in housing, water, sanitation, energy and other facilities. The census or statistical definition of an urban centre in Ghana is any settlement with a population of 5000 or more persons. Today more than four out of every ten Ghanaians live in a city or town of more than 5000 people (Ghana Statistical Service, 2012). Whereas only 9.4\% of the total population lived in urban settlements in 1931, this population shifted to $13.9 \%$ in $1948,23 \%$ in $1960,28.9 \%$ in 1970 , 31.3\% in 1984 and $43.9 \%$ in 2000 (see Table 1). To put it differently, by 1984, the number of urban settlements had increased nearly nine folds from 41 to 364 in 2000 whilst the associated population increased nearly fifteen folds from 570,597 persons to 8,278,636 persons (Songsore, 2010). One of the most pressing problems is, undoubtedly, the acute shortage of decent accommodation for people, especially the urban poor, that affects these rapidly growing cities and towns (MLGRD, 2012). With almost 51\% of Ghanaians living in urban areas, total stock of houses in the country as at 2010 was 3,392,745 (Ghana Statistical Service, 2012). About 90\% of housing in urban Ghana can be classified as informal, in that they are built without local authority control (UN-Habitat, 2011). 
Table 1. Trends of population growth and Urbanisation in Ghana-1921 to 2014.

\begin{tabular}{cccc}
\hline Year & Population $^{*}$ & Urban Percentage & Urban Settlements \\
\hline 1921 & $2,298,000$ & 7.8 & - \\
1931 & $3,163,000$ & 9.4 & 41 \\
1948 & $4,118,000$ & 13.9 & 98 \\
1960 & $6,727,000$ & 23.1 & 135 \\
1970 & $8,559,000$ & 28.9 & 203 \\
1984 & $12,296,000$ & 31.3 & 364 \\
2000 & $18,912,000$ & 43.9 & $423^{* *}$ \\
2010 & $24,659,000$ & 50.9 & 548 \\
$2014^{* * *}$ & $28,357,850$ & 51.9 & 503.9 \\
\hline
\end{tabular}

Source: Compiled based on Ghana Statistical Service, 2000, 2012. ${ }^{*}$ Population figures rounded-up to nearest thousands. ${ }^{* *}$ Projected.

There are many inconsistencies in data on the proportion of the urban population living in slums partly due to the various measurements of slum and projection methods used by different agencies. For instance, in 2001 the proportion of the urban population living in slums was estimated at 61\% (UN-Habitat, 2008) and 45\% in 2003 (UN-Habitat, 2011). However, in 2001 it was estimated at 69\%, 80.4\% in 1990 and 45\% in 2005 (Republic of Ghana, 2012b). Using housing type, Ghana Statistical Service (2012) estimated it at 5.9\% in 2010. Also, the State of the World Cities Report of 2012/2013 shows that $40 \%$ of Ghana's urban populations are living in slums. With an annual slum growth rate of $1.83 \%$ at 5.8 million people in 2010, the population of slum dwellers, by basis of arithmetic, can be estimated at 6,427,000 people by the end of 2017 when the National Urban Policy Action Plan will end (Ahmed, 2014a). In spite of these contradictions, it is clear that the slum rate in Ghana is high and increasing. It is therefore not surprising that the country has been listed in the State of the World Cities Report of 2006/2007 as one of the developing countries that is off track in finding solutions to slums and slum dwellers (UN-Habitat, 2007).

In Ghana, three types of slums can be identified - the Indigenous Communities, Migrant Community (popularly called "Zongo"), and the Newly Emerging Squatter Community. Table 2 shows the types of slums and their characteristics in Ghana. The indigenous communities have traditional homes with good infrastructure but without permits. The residents of migrant slum areas usually have lands released to them by the original owners of the lands but the infrastructure they put up is not durable as they have a "pilgrim mentality". The third group is the newly emerging squatter communities who virtually have no title to the lands they occupy. The second and third group contributes immensely to rapid expansion of slums. It should be noted that the typology of slums given by Afrane (2010) does not show when infrastructure is said to be fairly good or poor and does not give the socio-economic impact on slum dwellers. It also fails to prioritize the criteria used in distinguishing the types of slums in Ghana. Equally, what can be added is the spatial location of the types of slums within the city or town space. The indigenous slum communities are usually located within the centre, close to the central business area, and constitute the original settlement before urbanization. The migrant slums are found adjacent to the indigenous slums and are mostly occupied by first generation migrants and, together, the two forms the part of the city or town that has been "helmed inn" by rapid urbanization. The newly emerging squatter communities are found within the peri-urban areas of towns and cities and accommodate recent migrants from the rural areas. With the current escalation of peri-urbanization rates in Ghana, previously rural areas, which are rapidly becoming urban in character, urban fringe communities are constantly being converted to slums by the products of rural-urban migration.

\section{Methodology}

\subsection{The Study Area}

The Wa Municipality is located in the north-western part of Ghana lying within latitudes $1^{\circ} 40^{\prime} \mathrm{N}$ to $2^{\circ} 45^{\prime} \mathrm{N}$ and longitudes $9^{\circ} 32^{\prime}$ to $10^{\circ} 20^{\prime} \mathrm{W}$ (see Figure 1). According to a 2000 Population and Housing Census, the munici- 
Table 2. Slum typologies in Ghana.

\begin{tabular}{ccccc}
\hline Typology & Land Status & Housing Quality & Infrastructure & Housing Status \\
\hline Indigenous Communities & Traditional Homes & Mixed & Fairly Good & Without Permits \\
Migrant Community & Released by Owner & Poor & Poor-Good & Without Permits \\
Newly Emerging Squatter Community & Illegal No Title & Very Poor & Non-Existence & Without Permits \\
\hline
\end{tabular}

Source: Afrane, 2010.

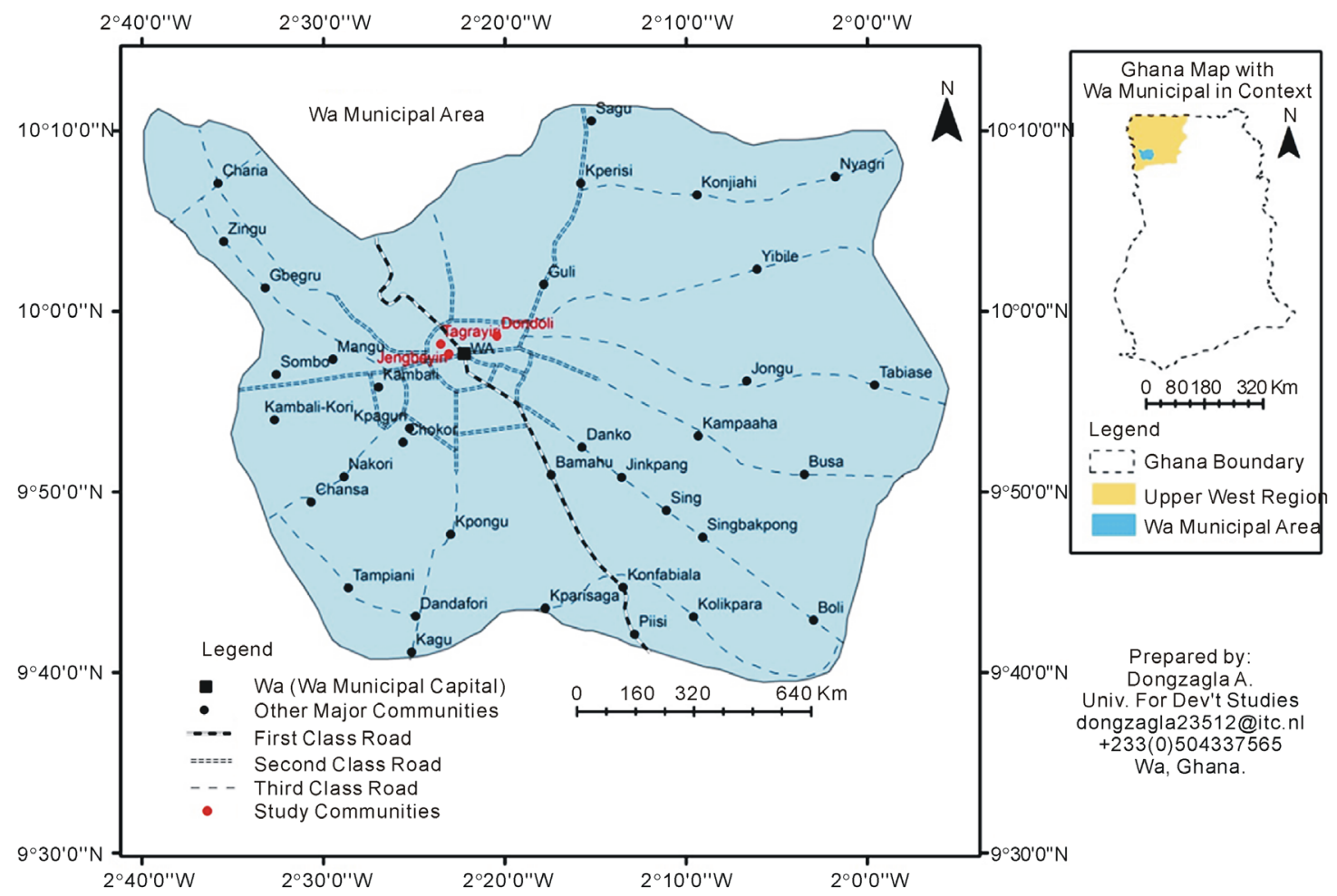

Figure 1. Map of study area.

pality had a total population of 98,675 (Ghana Statistical Service, 2002). The growth rate of the municipality varies between $2.7 \%$ for rural and $4 \%$ for the urban areas. In the year 2006 the municipality's population was estimated to be 119,387 (male: 57,985/female: 61,402), a percentage change of 20.9\%. Currently, the total population of the municipality stands at 127,284 with males constituting about 61,826 and females constituting 65,458 (Ghana Statistical Service, 2012). Jengbayiri and Tagirayiri are slum settlements located at the central part of the municipality close to the main market whilst Dondoli, another of the three selected slum settlements, is located on the eastern fringe of the municipality. Dondoli has about 2062 households, Jengbayiri has about 1586 whilst Tagirayiri has total households of about 1531 (Ghana Statistical Service, 2012). These three settlements possess the characteristics of slums - poor living standards, lack basic services (inadequate provision of sanitation facilities, water, etc.). Rapidly increasing population has its associated development implication in the areas of congestion, poor housing, education and health facilities, environmental sanitation and water supply, among others, that has affected the quality of life in these settlements. Lack of development control and financial constraints compounds the environmental challenge as dwellers continue to construct shanty houses regardless of the codes and ethics of building in the municipality.

Wa town is currently becoming a ridicule of human activities against the backdrop of the inability of the institutional arrangements and planning legislations to work against the deteriorating effects of unauthorized human activities. The undue delays in processing development applications and the bureaucracy involved are some of the key causes of the problems of physical development planning. In Wa there are indicators suggesting that 
the existing urban planning systems and governance structures are ill-equipped to cope with the anticipated infrastructural deficits. Rapid urbanization trends in Wa is characterized by persistently increasing unregulated urban growth, informal land development as well as weak enforcement (governance) of laws, regulations and procedures concerning land development control.

\subsection{Methods}

This study is primarily empirical in nature and in quest of identifying, describing and making coherence of observations found on the field rather than the development of exhaustive discussions or theoretical models of the development of slums and livelihood systems. Mixed methods, such as questionnaire survey of slum households, in-depth interviews, participant observation and walking interviews, formed the basis of a participatory method used in this study. The questionnaire, which was the main instrument for the study, comprised questions on demographic characteristics of households, housing facilities and livelihood activities (see Appendix). The study adopted a non-probability sampling technique (purposive sampling) in order to approach the problem with a specific plan of selecting predefined groups of slum areas in the municipality. Tagirayiri, Jengbayiri and Dondoli were purposively selected since they possess features and are largely characterized as slums within the municipality. In all 371 heads of households responded to the questionnaire as shown in Table 3. Wa Municipality has a total of 16,516 households of which 8805 live in slum settlements. Some 5195 of these households are located in Dondoli, Tagirayiri and Jengbayiri (Ghana Statistical Service, 2012). Households in Dondoli, Jengbayiri and Tagirayiri slums constituted the sample frame for the study. In order to have a fair representative sample size, the sample size was determined at a 95\% confidence level (at a 0.05 significance level) over the 5195 households living in the three selected slum areas for the study to yield a total of 371 sample size, using Miller and Brewer's (2003) formula. Proportions were allocated to the selected areas based on ration of the number of household living in each as shown in Table 3.

\section{Results}

\subsection{Socio-Economic Characteristics of Slum Dwellers}

In terms of age, $66.4 \%$ of the respondents fall below 45 years (see Figure 2) and this could be attributed to the

Table 3. Sample size distribution.

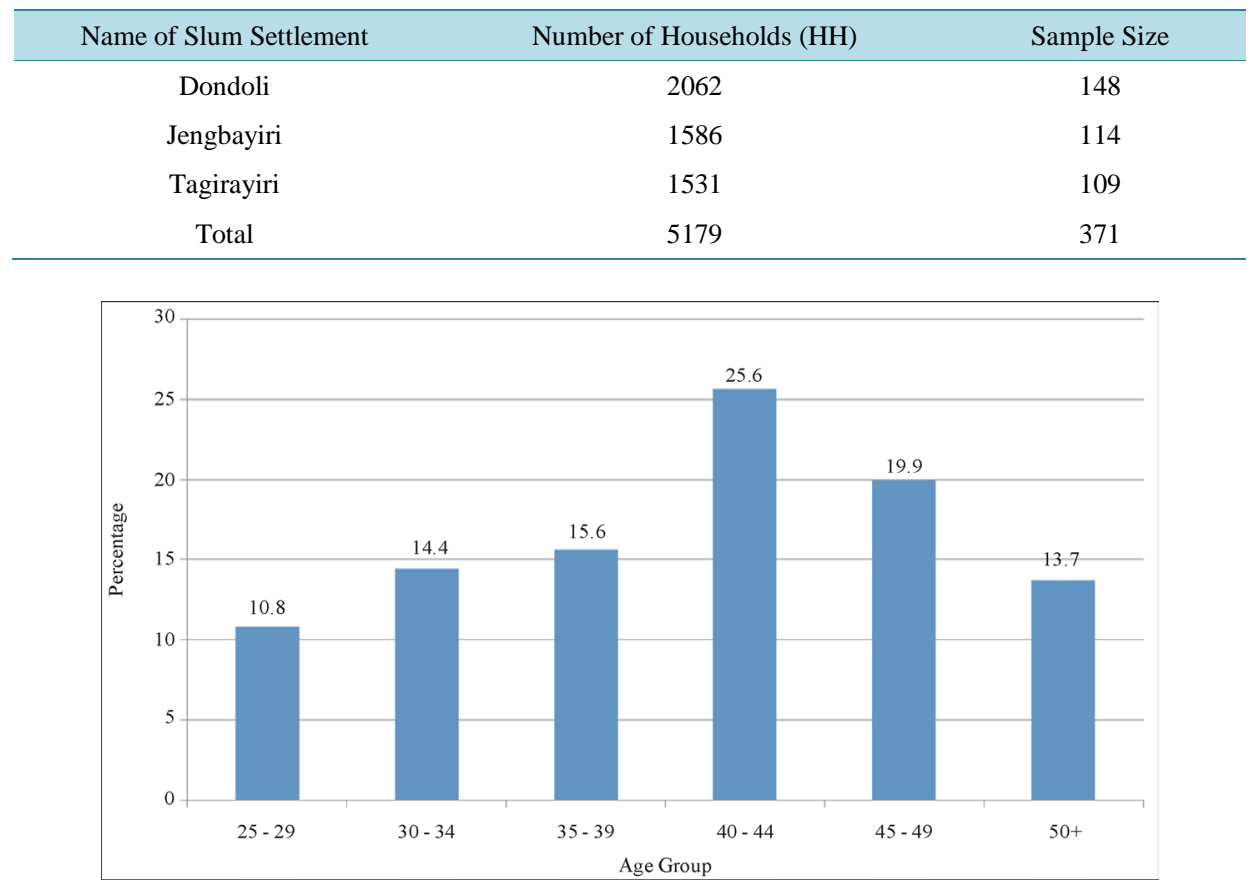

Figure 2. Age distribution of respondents (\%). 
mobility of labour in this productive young age group. Fall (1998) observed a similar occurrence by indicating that the mobility of migrants and labour, in general, decline at the age of about 40 years. The slum settlements are overcrowded. The average household size in the slum communities is 6.5 persons, which is higher than the municipality's, country's and UN's average of 5.1, 3.0 and 2.5 respectively. The relatively large household size is a common feature in Africa and this is greatly attributed to the extended family system that is commonly practiced.

Low levels of education and employment are also a peculiar feature of slum dwellers as $61.2 \%$ of the household heads have no formal education, $19 \%$ only obtained primary education whilst $9.9 \%$ have obtained secondary/technical education and the remaining 9.1 obtained tertiary education but can't find jobs. Sex and educational status of respondents are essential since females and males of certain age groups have preference for some types of livelihood activities. In this study, $45 \%$ of females without formal education prefer and are engaged in petty trading whilst $20 \%$ of males without formal education are engaged in farming. Another $33 \%$ of females and $30 \%$ of males without formal education are unemployed since they have no formal training that is required by employers. The informal sector is the largest employer of labor in these communities employing $86 \%$ of the slum dwellers and majority of those employed in this sector are poor due to low earnings. About $74.4 \%$ and $12.4 \%$ of the respondents earn monthly incomes of GH\$ 20.50 and GH\$ 87.50 respectively (see Table 4), which are far below the new daily minimum national wage of GH\$ 6.0 a day which amounts to about GH4 180.00 as the minimum average monthly income.

\subsection{Conditions and Characteristics of Slum Dwellings}

The study found that various types of houses dominate in Jengbayiri, Dondoli and Tagiriyiri slums of the Wa Municipality. Table 5 presents the number and types of houses in the study areas. Slum houses lack durability. Only $19 \%$ of the buildings in the slum communities are built with sandcrete blocks and are durable, $68 \%$ constitute houses built with sub-standard materials such as mud, wood, and bricks whilst the remaining $13 \%$ comprised of temporal structures. Households with low incomes prefer to stay in compound houses because of cheaper rents, yet closer to the main market where their livelihood activities are located.

Poor environmental conditions exacerbate urban poverty and the slum communities studied are underserved with water and sanitation services (see Table 6). It was found that $29.8 \%$ of the inhabitants have difficulty in assessing water and, hence, depends on vendors whilst $60 \%$ of the respondents considered sanitation as worse in their communities. As many as $17.3 \%$ of the respondents use the free range mode of defecation whilst $18.2 \%$ dispose off their household waste in the open space. Over $14 \%$ of slum households keep livestock of various kinds in their homes.

\subsection{Livelihood Systems, Constraints and Coping Mechanisms of Slum Households}

The livelihood systems of slum dwellers are similar to those within the peri-urban areas of Ghana and the developing world. The distribution shows that $19 \%$ of household heads have their occupations within the primary sector (farming), whilst $65.3 \%$ have their livelihoods categorized under the secondary/informal sector which comprises of tradesmen (carpenters, masons, auto mechanics, welders, etc.) and petty traders (vendors and stall traders), whereas the remaining $15.7 \%$ of household heads have their livelihood activities in the public/service sector (teachers, secretaries, office clerks, etc.). Moreover, $1.8 \%$ of household heads opted to have only one income-generating activity, provided it gave them enough income to meet all household needs. The loss of farmlands constraints livelihood systems as $57 \%$ of the farmers affirmed that the loss of previously owned agricultural land due to excessive sand winning, stone quarrying and residential activities challenges food availability as farmlands are destroyed at the expense of construction purposes.

Income diversification is the principal coping mechanism in slum communities. Majority (68\%) of household heads utilize what they termed "supplementary occupations", which consist of some form of trading activities. Others cope by reducing their daily meals and relying heavily on relatives and friends. A few $(0.05 \%)$ of slum household heads also marry women with worthy financial backgrounds so as to get their square meals. The inclusion of children in income generation activities is rampant. To supplement households' income, $26 \%$ of male household heads and $60 \%$ of female household heads engage their children in income generating activities in order to raise income towards the up keep of the household. Some (6.2\%) of household heads, who have no children, sell their valuables (land, animals, farm produce, clothes, etc.) in order to cope. Savings and invest 
Table 4. Diversity in household incomes and expenditures.

\begin{tabular}{|c|c|c|c|c|}
\hline \multirow{2}{*}{$\begin{array}{c}\text { Households } \\
\text { Income/Expenditure (Average) }\end{array}$} & \multicolumn{4}{|c|}{ Household Occupations } \\
\hline & $\begin{array}{l}\text { Farming } \\
\text { Households }\end{array}$ & $\begin{array}{l}\text { Trading } \\
\text { Households }\end{array}$ & $\begin{array}{l}\text { Salaried Workers } \\
\text { Households }\end{array}$ & $\begin{array}{l}\text { Artisans } \\
\text { Households }\end{array}$ \\
\hline Number of Households & $86(23.2 \%)$ & $138(37.2 \%)$ & $81(21.8 \%)$ & $66(17.8 \%)$ \\
\hline Household Average Monthly Income (GHథ) & 110 & 430 & 800 & 150 \\
\hline Food (GH4) & $16(14.5 \%)$ & 129 (30\%) & $360(45 \%)$ & $78(52 \%)$ \\
\hline Clothing (GHథ) & 8 & 10 & 20 & 12 \\
\hline Utilities (GHథ) & 12 & 14 & 22 & 15 \\
\hline Housing (GHథ) & 10 & 12 & 18 & 12 \\
\hline Light and Fuel (GHథ) & 12 & 13 & 20 & 16 \\
\hline Welfare (GHథ) & 17 & 13 & 22 & 14 \\
\hline Others (GHథ) & 20 & 12 & 18 & 13 \\
\hline Total Monthly Expenses & 112 & 142 & 210 & 160 \\
\hline
\end{tabular}

Table 5. Classification of houses in slum settlements.

\begin{tabular}{cccccc}
\hline Type of House & Jengbayiri & Dondoli & Tagirayiri & Total Number of Respondents & Percentage \\
\hline Compound Houses & 102 & 76 & 67 & 245 & $66.1 \%$ \\
Single Storey Houses & 6 & 3 & 0 & 9 & $2.5 \%$ \\
Semi Detached Houses & 10 & 12 & 9 & 31 & $8.3 \%$ \\
Temporal Structures & 37 & 26 & 23 & 361 & $23.1 \%$ \\
Total & 155 & 117 & 99 & & $100 \%$ \\
\hline
\end{tabular}

Table 6. Basic services and infrastructure.

\begin{tabular}{|c|c|c|c|c|c|}
\hline Infrastructure/Service & Jengbayiri & Dondoli & Tagirayiri & Total Number of HH & \% Distribution of Services to HH \\
\hline \multicolumn{6}{|l|}{ Water } \\
\hline Pipe $\overline{\text { Connection }}$ & 83 & 90 & 72 & 245 & 66.1 \\
\hline Bore Hole & 8 & 7 & 0 & 15 & 4.1 \\
\hline Vendors & 31 & 36 & 44 & 111 & 29.8 \\
\hline Total & 122 & 133 & 116 & 371 & 100 \\
\hline \multicolumn{6}{|l|}{ Electricity } \\
\hline Home Connection & 120 & 132 & 119 & 371 & 100 \\
\hline Total & 120 & 132 & 119 & 371 & 100 \\
\hline \multicolumn{6}{|l|}{ Bath Houses } \\
\hline$\overline{\text { Public Bath }}$ & 72 & 79 & 64 & 215 & 58 \\
\hline Private Bath & 45 & 50 & 52 & 147 & 39.6 \\
\hline Communal Bath & 6 & - & 3 & 9 & 2.4 \\
\hline Total & 123 & 129 & 119 & 371 & 100 \\
\hline \multicolumn{6}{|l|}{ Sanitary Facilities } \\
\hline Private Toilet & 22 & 20 & 16 & 58 & 15.7 \\
\hline Public Toilet & 77 & 85 & 87 & 249 & 67 \\
\hline Free Range & 22 & 27 & 15 & 64 & 17.3 \\
\hline Total & 121 & 132 & 118 & 371 & 100 \\
\hline \multicolumn{6}{|l|}{ Refuse Disposal } \\
\hline Container & 98 & 106 & 96 & 300 & 81 \\
\hline Open Space & 21 & 25 & 22 & 68 & 18.2 \\
\hline Burying & - & 3 & - & 3 & 0.8 \\
\hline Total & 119 & 134 & 118 & 371 & 100 \\
\hline
\end{tabular}


ments with financial institutions are the formal types of coping mechanisms for $10.7 \%$ of the household heads working within the public/service sector whilst 59\% of the petty traders have their savings through an informal means called "susu”. Slum households that engage in farming had almost no coping strategies for survival and 9.09\% of households hardly employ any coping mechanism in times of need. The absence of coping strategies for these household heads portrays the vulnerability contexts under which their families live.

\subsection{Challenges and Opportunities Available to Improve Slums}

The dubious nature of the legal status of slums is a universal challenge facing slum dwellers. In the study communities, $72 \%$ of the dwellers invade public and private lands for the construction of extensions to their houses that fail to meet urban planning regulations. The lack of slum improvement programs causes slum dwellers to live and plan on their own for survival, security and growth. Lack of space, conflict during demolition exercises by municipal authorities and residents' attitudes to change, to be clean and rightly do things are the main challenges towards slum improvement. Urban planning prolongs the procedures for granting tenure and implementing urban development plans. Lack of tenure results in inadequate information, hence public data on inhabitants is based on real estate and other organizational proceedings and records. Such information is not accessible for unofficial settlements, whose residents are effectively “invisible” to municipal authorities.

Formation of associations attracts support. Slum dwellers associations are platforms that attract support to enable them start micro businesses. They also mobilize each other to form voluntary groups where each group chooses one or more income generating activities to participate and learn skills of their interest. The study found that $19 \%$ of the slum dwellers enroll for life improvement programs designed by governments towards slum development. Slums are places of enterprise, innovation, creativity and hard work. The culture of slums is built on the unique knowledge that communities own and use to address the challenges they face. The locally community-produced knowledge is fundamental to the resilience, growth and vitality of slum settlers.

\section{Discussion}

The results suggest high levels of diversity in terms of skills, employment, income, expenditure, and coping strategies. This could serve as a dynamic resource and a source of resilience by utilizing the existing social capital within the slum communities. Contrary to Ahmed's (2014b) opinion of improving resilience through state urban interventions, this paper recalls the important role of social capital and urban diversity as the main factors in building resilience in slums. In the selected areas considered, 92\% of household heads have assets ranging from human capital (health, knowledge, skills, ability to labor, etc.), financial capital (reliable income sources, credit facilities, etc.) to social capital (networks, membership of groups, access to institutions, etc.). In terms of employment, there are also diversities under the informal sector, which comprises of artisans (carpenters, masons, auto mechanics and welders) and petty traders (vendors and stall traders). The results also support the assertion that slum dwellers are not necessarily a burden to urban populations if viewed in terms of place-based development (Pugalis et al., 2014).

From another perspective, because trickle down growth approaches to development have their own challenges, many result to autonomous coping strategies, which could potentially lead to mal-adaptation thereby worsening the conditions within which the poor live. For instance, many slum dwellers resort to open disposal of waste because of limited supply of improved disposal facilities. However, a move to neoliberal urbanism, urban governance and the market to provide solutions to urban poverty is a clear reflection of the limit of state interventions and the inability to meet urban demands in the light of limited state resources (STWR, 2010). With the institutional transition from government to governance, the role of the state in the provision of planned adaptation to the predicaments of slum dwellers have change in recent years. In such cases, slum dwellers are freed of the state, and welfare is a matter of individual responsibility through participation in the market. This further marginalizes the urban poor who are not competitive in adopting strong coping strategies. This, according to Watson (2009), neither the market nor communities have solutions to the diverse urban problems outside state reformed instruments of urban planning.

One legitimate concern from the selected areas considered is the state of urban planning and provision of social services. There is a mismatch between the current planning system and the needs that planning should address, especially in the slum areas. Therefore, rethinking of the mandate of urban planning as a response to sus- 
tainable development in the light of linking poverty and urbanization in low-income countries (the place of the urban poor in current planning system) seems appropriate. In the selected study areas, the search for new ways of balancing vulnerability and coping strategies present an urban dilemma for both planners and slum dwellers. Overcoming this urban dilemma in the informal sector leads to a quest for realigning planning with place-based characteristics. Whereas UN-Habitat (2005) argues that urban planning is part of the problem of the emergence of slums, Watson (2009) calls for a fundamental review of planning practices if it is to play any meaningful role in addressing issues of slums and urban poverty.

\section{Conclusion}

The findings revealed that livelihoods of slum households are generally concentrated around trading activities, although there are farmers, artisans and public/service sector workers in these settlements. This reflects the level of diversity in slums that could be utilized as dynamic resources. The constraints household heads encounter with various livelihoods to meet household needs include lack of assets, loss of farmlands to construction activities, unfavorable climatic conditions and competition among artisans for job placement. With these problems facing livelihood systems, different coping mechanisms are employed by household heads to meet basic needs. These survival mechanisms include undertaking supplementary occupations, collecting and recycling metallic and plastic materials, drawing on savings, reduction in meals, engaging children in trading activities and sale of valuable family properties. The results suggest that improving resilience in slums depends on the utilization of dynamic resources and skills. Future intervention in slums should focus on endogenous skills and social networks within the slums. Utilizing local skills and social networks make it easy to build trust and social capital needed for resilience in slums. Resilience must therefore be a function of endogenous skills and social capital within slums. Cities and towns in low-income countries must be ready in position to benefit from the diversity in slums rather than approaching it as a problem. The current state of affairs in terms of failed urban planning in the selected area prompts a revision of the current planning tools toward participatory urban planning and management. Formal planning authorities in Ghana regard their obligation to slums as a matter of resource constraint. The scope of planning will not only be determined by the resources available, but as a function of local politics and dialectics. Slum dwellers must be an integral part in the design and implementation of the interventions through participatory community scenario planning.

\section{References}

Adarkwa, K., \& Post, J., Eds. (2001). The Fate of the Tree; Planning and Managing the Development of Kumasi. Accra: Woeli Publishing Services.

Afrane, S. K. (2010). Slum Development in Ghana. London: Earth Scan Publication.

Ahmad, S., Choi, M. J., \& Ko, J. (2013). Quantitative and Qualitative Demand for Slum and Non-slum Housing in Delhi: Empirical Evidences from Household Data. Habitat International, 38, 90-99. http://dx.doi.org/10.1016/j.habitatint.2012.02.003

Ahmed, A. (2014a). Ghana National Urban Policy: Prospects and Challenges for Slum and Urban Management. Unpublished Manuscript, Town and Country Planning Department, Wa, Ghana.

Ahmed, A. (2014b). Factors in Building Resilience in Urban Slums of Dhaka, Bangladesh. Procedia Economics and Finance, 18, 745-753. http://dx.doi.org/10.1016/S2212-5671(14)00998-8

Aklin, M., Bayer, P., Harish, S. P., \& Urpelainen, J. (2015). Quantifying Slum Electrification in India and Explaining Local Variation. Energy, 80, 203-212. http://dx.doi.org/10.1016/j.energy.2014.11.063

Blaikie, W., \& Davis, C., (2004). At Risk, People’s Vulnerability and Disaster (p. 464). New York: Routledge.

Fall, A. (1998). Migrants Long Distance Relationship and Social Network in Dakar. Environment \& Urbanization, 10, 135-146. http://dx.doi.org/10.1177/095624789801000104

Floro, M., \& Swain, R. (2013). Food Security, Gender, and Occupational Choice among Urban Low-Income Households. World Development, 42, 89-99. http://dx.doi.org/10.1016/j.worlddev.2012.08.005

Fox, S. (2014). The Political Economy of Slums: Theory and Evidence from Sub-Saharan Africa. World Development, 54, 191-203. http://dx.doi.org/10.1016/j.worlddev.2013.08.005

Ghana Statistical Service (2002). 2000 Population and Housing Census. Accra: Ghana Statistical Service.

Ghana Statistical Service (2012). 2010 Population and Housing Census. Accra: Ghana Statistical Service. 
Gulyani, S., Bassett, E. M., \& Talukdar, D. (2014). A Tale of Two Cities: A Multi-Dimensional Portrait of Poverty and Living Conditions in the Slums of Dakar and Nairobi. Habitat International, 43, 98-107. http://dx.doi.org/10.1016/j.habitatint.2014.01.001

Miller, R. L., \& Brewer, J. D. (2003). A-Z of Social Research. London: Longman.

Nsiah-Gyabaah, K. (2009). The Urban Housing Challenge and Prospects for Meeting the Housing Needs of the Urban Poor in Ghana, CSIR/GIA (Eds.): Proceedings of the 2009 National Housing Conference, Accra, October 7-8, 2009.

Parikh, P., Chaturvedi, S., \& George, G. (2012a). Empowering Change: The Effects of Energy Provision on Individual Aspirations in Slum Communities. Energy Policy, 50, 477-485. http://dx.doi.org/10.1016/j.enpol.2012.07.046

Parikh, P., Parikh, H., \& McRobie, A. (2012b). The Role of Infrastructure in Improving Human Settlements. Proceedings of the ICE-Urban Design and Planning, 166, 101-118. http://dx.doi.org/10.1680/udap.10.00038

Parikh, P., Fu, K., Parikh, H., Mcrobie, A., \& George, G. (2015). Infrastructure Provision, Gender, and Poverty in Indian Slums. World Development, 66, 468-486. http://dx.doi.org/10.1016/j.worlddev.2014.09.014

Patel, A., Koizumi, N., \& Crooks, A. (2014). Measuring Slum Severity in Mumbai and Kolkata: A Household-Based Approach. Habitat International, 41, 300-306. http://dx.doi.org/10.1016/j.habitatint.2013.09.002

Pugalis, L., Giddings, B., \& Anyigor, A. (2014). Reappraising the World Bank Responses to Rapid Urbanisation: Slum Improvements in Nigeria. Local Economy, 29, 519-540. http://dx.doi.org/10.1177/0269094214541377

Republic of Ghana (2012a). National Urban Policy. Accra: Ministry of Local Government and Rural Development (MLGRD).

Republic of Ghana (2012b). Ghana Shared Growth Development Agenda I. Accra: National Development Planning Commission.

Songsore, J. (2010). The Urban Transition in Ghana: Urbanization, National Development and Poverty Reduction. Study Prepared for the IIED as Part of Its Eight Country Case Studies on Urbanization.

Stoler, J., Tutu, R. A., \& Winslow, K. (2015). Piped Water Flows but Sachet Consumption Grows: The Paradoxical Drinking Water Landscape of an Urban Slum in Ashaiman, Ghana. Habitat International, 47, 52-60. http://dx.doi.org/10.1016/j.habitatint.2015.01.009

STWR (2010). The Seven Myths of Slums: Challenging Popular Prejudices about the World's Urban Poor. London: Share the World's Resources.

Thorn, J., Thornton, T. F., \& Helfgott, A. (2015). Autonomous Adaptation to Global Environmental Change in Peri-Urban Settlements: Evidence of a Growing Culture of Innovation and Revitalisation in Mathare Valley Slums, Nairobi. Global Environmental Change, 31, 121-131. http://dx.doi.org/10.1016/j.gloenvcha.2014.12.009

Tumwebaze, I. K., Niwagaba, C. B., Günther, I., \& Mosler, H. J. (2014). Determinants of Households' Cleaning Intention for Shared Toilets: Case of 50 Slums in Kampala, Uganda. Habitat International, 41, 108-113. http://dx.doi.org/10.1016/j.habitatint.2013.07.008

UN-Habitat (2005). The Legacy of the Urban Management Programme. Nairobi: UN-Habitat.

UN-Habitat (2007). State of the World's Cities 2006/2007. Nairobi: UN-Habitat.

UN-Habitat (2008). The Challenge of Slums: Global Report on Human Settlements. London: Earthscan Publications.

UN-Habitat (2009). State of the World's Cities: Harmonious Cities 2008/2009. London: Earthscan Publications.

UN-Habitat (2011). Ghana Housing Profile. Nairobi: UN-Habitat.

UN-Habitat (2012). State of the World's Cities 2012/2013. Nairobi: UN-Habitat.

United Nations (2011). The Millennium Development Goals Report, 2011. New York: United Nations.

Watson, V. (2009). The Planned City Sweeps the Poor Away: Urban Planning and 21st Century Urbanization. Progress in Planning, 72, 151-193. http://dx.doi.org/10.1016/j.progress.2009.06.002 


\section{Appendix: Household Questionnaire}

Name of Community:

Date of Interview:

Section A: Demographic Characteristics

1) Please indicate appropriately on the table below:

Sex Age Marital Status Number of Children Length of stay in community size

2) Where do you come from?
(a) Community\{ \}
(b) Within the Municipality\{ \}
(c) Within the Region $\{\quad\}$
(d) Outside the Region $\{\quad\}$

3) What is your religious affiliation?
(a) Islam \{ \}
(b) Christianity $\{\quad\}$
(c) Traditionalist $\{\quad\}$
(d) Others

4) What is your level of education?
(a) Primary \{ \}
(b) Middle/JHS \{ \}
(f) Never attended School \{
(c) SHS \{ \}
(d) Tertiary \{ \}
(e) Adult Literacy $\{\quad\}$

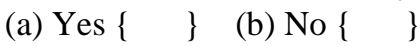

5) Are you employed? (a) Yes \{
6) If "Yes", what is your occupation?

7) If "No", what do you do for a living?

8) How much do you earn on the average per month?
(a) $\mathrm{GH} \$ 1-100\{\}$
(b) GH\$101 - 200
(c) GH\$201 - $300\{\quad\}$
(d) GH\$301 - $400\{\quad\}$
(e) GH\$401 - 500\{\}
(f) Others (specify)

9) Please indicate your monthly expenditure by ticking the appropriate category

\begin{tabular}{l} 
Item \\
\cline { 2 - 5 } \\
\cline { 2 - 5 } Food \\
Clothing
\end{tabular}

10) How much do you save per month?
(a) GH\$1 - 100 \{
(b) GHథ101 - 200 \{
\}
(c) GHథ $201-300\{$
(d) GH\$301 - $400\{\quad\}$
(e) GHष401 - 500\{\}
(f) Others (specify)

\section{Section B: Housing Characteristics}

11) What type of House do you stay in?
(a) Flat $\{\quad\}$
(b) Compound \{\}
(c) Detached \{ \}
(d) Semi-Detached \{\}
(e) Single Storey \{ \}
12) When was the house built?
(a) Before 1980\{\}
(b) 1981-1990 \{ \}
(c) $1991-2000\{\}$
(d) $2001-2010\{\}$
(e) 2011-To date \{ \}

\section{Household characteristics}
13) How many households are in the house you stay in?
(a) $1-3\{\}$
(b) $4-6\{\}$
(c) $7+\{\quad\}$
14) How many habitable rooms are in this house?
(a) $1-3\{\}$
(b) $4-6\{\}$
(c) $7+\{\}$

15) How many people occupy a room?

(a) $1-3\{\quad\}$

(b) $4-6\{\}$

(c) $7+\{\quad\}$

16) Have you ever encountered problems with city authorities regarding your stay here? 
(a) Yes $\{\quad\}$ (b) No $\{\quad\}$

17) If yes what kind of encounter?
(a) Force evictions \{\}
(b) Demolition \{ \}
(c) Restructuring $\{\quad\}$
(d) Others

\section{House Ownership/ Holding Status}

18) Are you the owner of the house you stay in?

If "yes”, answer question 21 - 27 and "no", skip to Q28
19) How did you acquire the house?
(a) By purchase \{\}
(b) inheritance $\{\quad\}$

(c) Others (specify)

20) If by purchase, do you have title to the land?

21) Do you have a building permit?

(a) Yes \{

(a) Yes $\{\quad$ (b) No \{\}

22) If no, who gave you the permission to build?

\section{Building Materials}

23) Please thick appropriately from the table below

\begin{tabular}{|c|c|c|c|c|c|}
\hline Floor or Foundation & Tick & Wall & Tick & Roof & Tick \\
\hline Cement/Concrete & & Cement/Concrete & & Corrugated Metal & \\
\hline Sandcrete & & Sand Crete & & Sheet Asbestos & \\
\hline Landcrete & & Land Crete & & Tiles & \\
\hline Burnt Bricks & & Burnt Bricks & & Concrete & \\
\hline Mud & & Mud & & Wood/Thatch & \\
\hline
\end{tabular}

24) Were you involved in the choice of materials for the construction of the house?

(a) Yes $\{\quad\}$ (b) No \{ \}

25) If yes, what motivated your choice?
(a) Affordable $\{\quad\}$
(b) Design $\{\quad\}$
(c) Durable $\{\quad\}$
(d) Others

26) How often do you maintain your house?
(a) Monthly \{ \}
(b) Yearly \{ \}
(c)Two years $\{\quad\}$
(d) Others (specify)

Housing facilities

27) Please tick appropriately whether/where these facilities are located in the house you stay in?

\begin{tabular}{ccccccc}
\hline \multirow{2}{*}{ Facility } & Availability & \multicolumn{3}{c}{ Condition } \\
\cline { 3 - 5 } & Internal & External & Good & Fair & Poor \\
\hline Bath & & & & & \\
Toilet & & & & \\
Kitchen & & & & \\
Storeroom & & & \\
Water & & & \\
Electricity & & & & \\
\hline
\end{tabular}

28) What is the average waiting time for accessing the following services and facilities?

\begin{tabular}{|c|c|c|c|c|c|}
\hline \multirow{2}{*}{ Facility } & \multicolumn{4}{|c|}{ Time } & \multirow{2}{*}{ Others } \\
\hline & 1 - 5 mins & 6 - 10 mins & $11-15$ mins & 16 - 20 mins & \\
\hline \multicolumn{6}{|l|}{ Bathroom } \\
\hline \multicolumn{6}{|l|}{ Toilet } \\
\hline Water & & & & & \\
\hline
\end{tabular}


29) Tick any of the following observation at your place of residence

\begin{tabular}{|c|c|c|c|c|c|}
\hline Item & Exposed Foundation & Cracked Walls & Leaking Roofs & Unpainted & Poor Sanitation \\
\hline
\end{tabular}

30) What is the main factor that influenced your residential location?
(a) Physical Location \{ \}
(b) Accessibility to services and facilities $\{\quad\}$
(c) Housing typology \{ \}
(d) Peace and security \{\}
(e) Affordability \{ \}

31) What is the distance from your place of residence to your place of work?
(a) Less than $1 \mathrm{~km}\{\quad\}$
(b) $2-5 \mathrm{~km}\{\quad\}$
(c) $6-10 \mathrm{~km} \mathrm{\{ \quad \}}$
(d) More than $10 \mathrm{~km} \mathrm{\{ \quad \}}$

32) What is your means of transport to your place of work?
(a) By Foot $\{\quad\}$
(b) Bicycle $\{\quad\}$
(c) Motor bicycle $\{\quad\}$
(d) Private car $\{\quad\}$
(e) Public transport $\{\quad\}$

Water \& Sanitation

33) What is your source of water?
(a) Stand pipe $\{\quad\}$
(b) Borehole $\{\quad\}$
(c) Well $\{\quad\}$
(d) Buy from Vendors $\{\quad\}$
(e) Others (Specify)

34) How often does the source of water flow?
(a) Regularly \{ \}
(d) Others (Specify)
(b) Weekly \{ \}
(d) Fortnightly \{ \}
35) Where do you access water if it does not flow?
36) How do you dispose off your refuse?
(a) Burying \{ \}
(b) burning $\{\quad\}$
(c) Dumping $\{\quad\}$

(d) house-house collection $\{\quad\} \quad$ (e) other (specify)

37) What is/are the method(s) of human excreta disposal?

$\begin{array}{llll}\text { (a) W/C }\{\} & \text { (b) Free-range }\{\} & \text { (c) KVIP }\{\} & \text { (d) Others (specify) }\end{array}$

38) What kind of drainage system do you have in your house?

(a) Open space $\{\quad\}$ (b) Concrete gutters $\{\quad\}$ (c) Soak away $\{\quad\}$ (d) other (specify)

39) What are the problems associated with this area with respect to the source of Water?

40) What are the problems associated with the drainage systems, sanitation and human excreta disposal?

41) Are you content with the water and sanitation situation in the community?
(a)Yes $\{\quad\}$ (b) No \{ \}
42) If "No", why are you not content with the situation?
Section C: Livelihood Characteristics

43) Do you have another source of Livelihood different from your occupation?

(a) Yes $\{\quad\}$ (b) No $\{\quad\}$

If "No" skip to Q53

44) If "Yes", what kind of livelihood activities do you engage in to survive?

45) Among these livelihood systems, which one is your main source of income?

46) What factors influenced your choice of Livelihood?

47) Do you have any problem pursuing this livelihood strategy?

48) If "Yes" what problems do you have in pursuing this strategy?

(a) Yes \{\}$\quad$ (b) No $\{\quad\}$

49) If the problems are within your means, what have you done to redress these restrictions?

50) Is the income you earn from these livelihood systems enough to cater for your needs? If "Yes/ No", why?

51) What kind of coping strategies do you undertake in times of need? 
52) Would you be interested in other strategies for achieving your objectives?
(a)Yes $\{\quad\} \quad$ (b) No $\{\quad\}$
53) If "Yes", what type?
(a) Other technologies $\{\quad\}$
(c) New land entitlements $\{\quad\}$
(b) new market opportunities $\{\quad\}$
54) What other kinds of support is needed for you to improve your livelihood?

55) Are you satisfied with the environment your livelihood system is located?
(a) Yes \{
(b) No $\{\quad\}$
56) If "Yes", how does the environment facilitate your livelihood system?

57) How do you cope with the situation?

58) What are the major constraints you have that hinders your coping mechanisms? 